\title{
An Analysis of Translation Shift of Adjective Phrases in the Subtitle of 2019 Movie "Jumanji: The Next Level"
}

\author{
Mutia Aryanti ${ }^{1}$, Dyah Raina Purwaningsih ${ }^{2}$, Raden Pujo Handoyo ${ }^{3}$ \\ Universitas Jenderal Soedirman 123 \\ dyah.purwaningsih@unsoed.ac.id ${ }^{2}$ (Corresponding Author)
}

Article History:

First Received:

$28 / 10 / 2021$

Final Revision:

$10 / 12 / 2021$

Available online:

$30 / 12 / 2021$

\begin{abstract}
The research aims to identify the translation shift and describe the equivalence of adjective phrases found in the Jumanji: The Next Level movie and its subtitling. To get the analysis result, translation shift proposed by Catford (1965) and degree of equivalence proposed by Bell (1991) are used in this research. The research is conducted by using descriptive qualitative method in analyzing the data and total sampling technique. The data of this research are 104 English adjective phrases taken from Jumanji: The Next Level movie and their subtitles in Indonesia that is translated by Pein Akatsuki. The results of this research for the types of translation shift are 2 level shift, 59 structure shift, 19 class shift, 22 unit shift, and 2 intra system shift. Meanwhile, the result for the equivalence are 64 complete meaning, 3 increased meaning, 26 decreased meaning, and 11 non equivalent meaning in the category of different meaning. This current research explores adjective phrase that has not been much discussed by other scholars.
\end{abstract}

Keywords: translation shift, equivalence, adjective phrase, subtitle, Jumanji: The Next Level

http://jos.unsoed.ac.id/index.php/jes

\section{INTRODUCTION}

Translation is a general term referring to the transfer of thoughts and ideas from onelanguage to another, whether the language is in written or oralform, whether the languages have established orthographies ornot; or whether one or both languages is based on signs, aswith signs of the deaf. (Brislin, 1976). This kind of activity has been applied in written language and spoken language of various texts. In Indonesia, there are many literary works such as poems, novels, short stories, and movies that use foreign language that have been translated into Indonesian.

In the field of translation, subtitle is the product of translation in the movies, TV shows, and pre-recorded videos found in television or cinema. Subtitles are usually positioned at the lower part of the screen with maximum of two lines of subtitles 
that can be presented at a time. In a video document, subtitles have a great importance to help people to understand the meaning of dialogues. Furthermore, it also helps a lot of deaf and the hard of hearing people to get the meaning from what they are watching.

Subtitles for films are the end result of translation and should be equivalent. Equivalence refers to the fact that the target language's product of translation has a similar meaning to the source language. As Nida (1975) stated translation is the process of producing the closest natural equivalent of the source language's message in the target language. It means that people who read the subtitles as translations product while watching a movie will get the right messages if the subtitles are equivalent. Subtitles are very useful for viewers who do not understand foreign languages, especially English and it can make the viewers get the messages from the movie through conversation. However, sometimes the shift in the subtitle translation still have some words from source language to target language that is not commensurate.

The translator must pay close attention to both the source and target languages' cultures during the translation process, as each language has its own set of rules. Nida and Taber (1969: 35) said that the same grammatical construction may represent a number of relationships, and have many different meanings. Therefore, translators occasionally make some changes or shifts. This shifts can occur in grammar, structure, or word class. According to Catford (1965), the term "translation shift" refers to the little linguistic changes that occur between the source and target texts. There are two types of translation shift proposed by Catford (1965: 73). The first is 'level shift' and the second is 'category shift', which is aimed at achieving good equivalence for the quality of translation result. Category shift consists of class shift, structure shift, unit shift, and intra system shift. In addition, the existence of a shift in translation is quite important to produce an acceptable and natural translation.

There are many groups of words that the translation shift can be observed when translating text from English into Indonesian, one of them is adjective phrase. "Adjective phrase is a group of words that modifies a noun" (Todd, 1987: 60). The term "adjective phrase" refers to a phrase in which an adjective serves as the phrase's head. Besides adjective phrases, the English language recognizes four grammatical forms: adverb phrases, prepositional phrases, verb phrases, and noun clauses.

The translation shift phenomenon is often found in movie subtitles. For example in Jumanji: The Next Level movie subtitles. In this movie, there are many kind of shifts that can be found based on Catford's theory so that the writer is interested to observe the translation shift in this movie. Furthermore, in this research, the writer focuses on adjective phrase to analyze the translation shift and its equivalence from the movie Jumanji: The Next Level. Research on noun phrase translation was conducted which was aimed at classifying translation shift of noun phrase and describing the equivalence and non equivalence of the shift by Ratnawati (2013). Another reseearch on verb phrase was conducted by Permadi (2013) which was aimed at identifying the translation shift of verb phrase and describing the equivalence of verb phrase found in the film entitled the Expendables 2. The writer chooses this movie 
because according to imdb.com, posted on 15 August 2018, this movie is one of the most anticipated movies in 2019. Besides, according to Liputan6.com, posted on 9 December 2019, it is also the number 1 movie of the week in the first week of broadcast in Indonesian cinemas. The large number of public enthusiasm for watching this movie is also accompanied by the many Indonesian subtitles that can be found on the internet. This movie also has a storyline and characters that are quite unique. Talking about video game called Jumanji, each character also has strengths and their respective characteristics. Thus, the characters often talk about their strengths, weaknesses, and what they feel in the form of an adjective or adjective phrase. Therefore, the writer is interested in discussing the adjective phrase uttered by the characters in this movie, especially in terms of translation into Indonesian. Next, the subtitles chosen by the writer are subtitles belonging to Pein Akatsuki, who is one of the translators in the field of Indonesian film subtitles. According to medcom.id, posted on 4 July 2018, Pein Akatsuki is one of the most popular subtitlers in Indonesia with hundreds of western films / series translated and distributed freely to some websites on the internet. Pein Akatsuki is also included in Indonesian Data \& File Library (IDFL) forum which was formed on February 20, 2012. This forum has many topics of discussion, but its main focus is to share movie or serial file links and subtitles.

In the process of analyzing, the writer focuses on two theories from Catford (1965) about translation shift and the modification of Bell (1991) about translation equivalence.

To begin, Catford's theory categorizes shift into two types: level shift and category shift. Structure shift, class shift, unit shift, and intra system shift are all subcategories of category shift

\section{Level Shift}

According to Catford (1965: 73), "A shift level is a condition in which source language item at one linguistic level has a translation equivalent at different level in the target language." Catford also points out that the commonest level shift found in translation is shift from grammar into lexis or lexis into grammar. For instance, I am working hard is translated into Saya sedang bekerja keras.

\section{Category Shift}

According to Catford (1965: 76), "Category shift are departures from formal correspondence in translation". It refers to unbounded and rank-bounded translation. Category shift includes structure, class, unit, and intra system shifts.

\subsection{Structure Shift}

Catford (1965: 77) states that "Structure is an arrangement of elements. The elements of structure of the English are $\mathrm{P}$ (predicator), S (subject), C (complement), A (adjunct) and also phrase structure MH (modifier + head)". A structure shift occurs when the source text and the target text have a different grammatical structure. For instance, she is beautiful is translated into dia cantik. It shows there is a change in grammatical structure, from $\mathrm{S}+\mathrm{V}+\mathrm{Adj}$ into $\mathrm{S}+\mathrm{Adj}$.

\subsection{Class Shift}

Cited from Catford (1965: 78), "A class as 'that grouping of members of a given unit which is defined by operation in the structure of the unit next above'." When the translation equivalent of a source language item is assigned to a different class 
than the original item, class shift occurs. For example, giving me a hug is is translated into peluk aku. The term class is transformed from a noun (hug) to a verb (peluk).

\subsection{Unit Shift}

When the target language's translation equivalent of a source text unit at one rank is allocated to a different rank, unit shift happens. It encompasses the transformation of morphemes into words, words into phrases, clauses into sentences, and vice versa. As Catford (1965: 79), "By unit shift we mean changes of rank that departures from formal correspondence in which the translation equivalent of a unit at one rank in the source language is a unit at different rank in the target language". For instance, from the source language impossible translated into tidak mungkin in Indonesian. There is a unit shift because word in SL change into phrase in TL.

\subsection{Intra System Shift}

According to Catford (1965: 79), "Intra system shift could only mean a departure from formal correspondence in which one system in the source language has as its translation equivalent a different non-corresponding system in the target language". In other words, intra system shifts are those that occur within a system. Each language has its unique numeration, deixis, and article systems, among other things. When a sentence is singular in the source text but plural in its textual equivalent, or vice versa, this is referred to as intra system shift. For instance, the word glasses in English translated into kacamata in Indonesian. There is an intra system shift because plural form in SL translated into singular form in TL.

Second, Bell (1991: 6) states that "Texts written in different languages might be equal to varying degrees (completely or partially), in terms of realization and rank. A classification based on the idea into equivalent and non-equivalent meanings, which are further classified into fully and partially equivalent, as well as nonequivalent meanings. He classifies the equivalent and non-equivalent meanings in the following explanation.

\section{Equivalent}

The term "equivalent" is separated into two categories: fully equivalent and partly equivalent.

\subsection{Fully Equivalent (Complete Meaning)}

When the meaning included in the source language text is totally translated into the target language text, this is referred to as complete meaning. For example, the term 'red bag' is translated as 'tas merah'. The source language's message is precisely translated into the target language..

\subsection{Partly Equivalent}

Partly equivalent is divided into increased meaning and decreased meaning. Increased meaning happens when additional information is realized through the inclusion of new meaning that is not present in the original language text. For example, the term 'warm' is translated as 'hangat dan terang'. The translator adds the word 'terang' in the target language here. Meanwhile, decreased meaning occurs when portion of the meaning contained in the source language text is omitted in the target language text. For instance, the noun phrase 'bedroom mat' is translated as 'tempat tidur' in Indonesian.

\section{Non-Equivalent}

Non-equivalent is divided into different meaning and no meaning. 


\subsection{Different Meaning}

Different meaning happens when the translator modifies the information included in the source language text by employing terms with different meanings in the target language. For example, 'feeding my sister, Tina' is translated as 'sarapan bersama saudaraku, Tina'. The term 'feeding', which translates as 'memberi makan' or 'menyuapi' in Indonesian, is translated differently as 'sarapan bersama'.

\subsection{No Meaning}

It is when the translator omits words or expressions from the source language text, the target language text becomes devoid of all information contained in the source language text. For example, when the phrase 'young and free' is translated into 'bebas,' the word 'young' is lost or completely not translated.

Translating English adjective phrases into Indonesian is not an easy task. This is because the English and Indonesian adjectival forms are sometimes different, making it interesting and needing to be analysis. Therefore, the writer conducts a research entitles An Analysis of Translation Shift of Adjective Phrases in The Subtitle of 2019 Movie "Jumanji: The Next Level". Moreover, through this research, the writer wants to investigate the translation shift of adjective phrase and describe the equivalence of adjective phrase in Jumanji: The Next Level movie and its subtitling.

\section{RESEARCH METHOD}

This research uses qualitative method because the data are examined from a shift in the translation of adjective phrases from English to Indonesian and it needs researcher's explanation and interpretation. In addition, the data also focus on how the translations in target language are equivalent by comparing the meanings of both source and target language so it cannot be measured or analyzed statistically.

The data of this research are 104 English adjective phrases and their subtitles in Indonesian taken from Jumanji: The Next Level movie. The data source of this research are Jumanji: The Next Level movie produced by Columbia Pictures in 2019 and its subtitles that is translated by Pein Akatsuki.

The writer uses documentation method for collecting the data by watching the original film of Jumanji: The Next Level and its Indonesian subtitles, underlining the English sentence containing adjective phrase, writing every sentence which contains adjective phrase in source language and target language on the paper, and coding the data. Furthermore, in analyzing the data, the procedures are identifying translation shift of the data, describing and checking the equivalence, and concluding the data.

\section{RESULT AND DISCUSSION}

Each finding is presented in a table that includes the frequency and percentage of occurrence of the data.

\section{The Types of Translation Shift}

According to Catford (1965) classification of translation shift, the researcher finds 104 data of adjective phrases that consist of level shift, structure shift, class shift, unit shift, and intra system shift. The following table shows the result of the data found in Jumanji: The Next Level movie and its subtitling. 
Table 1. Result of The Types of Translation Shift

\begin{tabular}{|c|l|c|c|}
\hline No & Types of Translation Shift & Number & Percentage \\
\hline 1. & Level Shift & 2 & $1.92 \%$ \\
\hline 2. & Structure Shift & 59 & $56.74 \%$ \\
\hline 3. & Class Shift & 19 & $18.27 \%$ \\
\hline 4. & Unit Shift & 22 & $21.15 \%$ \\
\hline 5. & Intra System Shift & 2 & $1.92 \%$ \\
\hline \multicolumn{2}{r|}{ Total } & $\mathbf{1 0 4}$ & $\mathbf{1 0 0 \%}$ \\
\hline
\end{tabular}

The 104 data consist of 2 level shift, 59 structure shift, 19 class shift, 22 unit shift, and 2 intra system shift. Based on the finding, structure shift is the most frequently shift that occurs in the translation of adjective phrases in Jumanji: The Next Level movie with percentage 56.74\%. Meanwhile, level shift and intra system shift are the least frequent shifts which occur only 2 times with percentage $1.92 \%$.

\subsection{Level Shift}

Level shift is a condition in which an item in the source language at one linguistic level has a translation counterpart in the target language at a different linguistic level (1965: 73). Typically, a level shift in translation is signified by the source language's grammar being translated into the target language's lexis. The following is an example.

Table 2. Level Shift: Grammar to Lexis

\begin{tabular}{|c|l|l|}
\hline \multicolumn{1}{|c|}{ Code } & \multicolumn{1}{|c|}{ Source Language } & \multicolumn{1}{c|}{ Target Language } \\
\hline LS1/21:56/CM & $\begin{array}{l}\text { Faster than a horse, if } \\
\text { you can believe that. }\end{array}$ & $\begin{array}{l}\text { Lebih cepat dari kuda, } \\
\text { jika kau } \\
\text { mempercayainya. }\end{array}$ \\
\hline
\end{tabular}

The level shift is between the form of comparative 'adjective $+e r$ ' in the SL and the word 'lebih' in the TL. In English, comparative is used to compare differences between two objects. In order to get the equivalent translation result in Indonesian, therefore the use of word 'lebih' is used to represent it. The form of comparative degree in English is part of grammatical structure with fixed pattern. Meanwhile, in Indonesian, there is no specific grammatical structure; we can simply add the word lebih to indicate the comparative degree.

\subsection{Category Shift}

Catford classified category moves into four categories. He defined category shifts as departures from or modifications of formal writing in translation (1965: 76). Structure shifts, class shifts, unit shifts, and intrasystem shifts are all examples of category shifts.

\subsubsection{Structure Shift}


Structure shift is a change in grammatical structure between source text and target text. Usually, the most frequent or dominant category shift that appears in translation is structure shift. The analysis of sructure shift are given below.

Table 3. Structure Shift: $A d v+A d j+P r e p+A d v$ into Pro $+A d v+A d j$

\begin{tabular}{|l|l|l|}
\hline \multicolumn{1}{|c|}{ Code } & Source Language & Target language \\
\hline SS1/4:41/CM & $\begin{array}{l}\text { Is it really cold in } \\
\text { here? }\end{array}$ & $\begin{array}{l}\text { Di sini sangat } \\
\text { dingin. }\end{array}$ \\
\hline
\end{tabular}

In the example, the phrase 'really cold in here' is translated into 'Di sini sangat dingin'. It can be seen the structure in SL is Premodifier (really) + Head (cold) + Postmodifiers (in here). However if each word is analyzed for its part of speech, it will have a sequence like, adverb (really) + adjective (cold) + preposition (in) + adverb (here). Meanwhile, the order of part of speech in the translation of adjective phrase in TL is pronoun (di sini) + adverb (sangat) + adjective (dingin). Therefore it is clearly seen that there is a change in the structure of sequence of part of speech from source language to target language. The shift in this translation is from Adverb + Adjective + Preposition + Adverb into Pronoun + Adverb + Adjective.

\subsubsection{Class Shift}

The term "class shift" refers to a change in the word class between the source and target texts. It can be from Adjective (Adj) to Noun (N), Verb (V) to Adjective (Adj), Adverb (Adv) to Verb (V), or vice versa. (Catford, 1965). The analysis of class shifts are given below.

Table 4. Class Shift: AdjP into VP

\begin{tabular}{|l|l|l|}
\hline \multicolumn{1}{|c|}{ Code } & Source Language & Target language \\
\hline CS1/11:34/DM & $\begin{array}{l}\text { I've been a little } \\
\text { worried about him. }\end{array}$ & $\begin{array}{l}\text { Aku cuma } \\
\text { mengkhawatirkan } \\
\text { dia. }\end{array}$ \\
\hline
\end{tabular}

From the example above, it can be seen that there is a shift in its class. In the source language, 'little worried about him' is called as adjective phrase because it describes the feeling of fear or afraid of the pronoun ' $I$ '. Meanwhile, in the target language, 'mengkhawatirkan dia' is called verb phrase because the head of the phrase is a verb (mengkhawatirkan). Thus, this class shift happens when adjective phrase (little worried about him) in the source language is translated into verb phrase (mengkhawatirkan dia) in the target language.

\subsubsection{Unit Shift}

Unit shift is a change of rank/unit from source language to target language. this shift occurs in the change of word into phrase, phrase into clause, clause into sentence, or vice versa.

Table 5. Unit Shift: Phrase to Word

\begin{tabular}{|l|l|l|} 
Code & Source Language & Target language \\
\hline
\end{tabular}




\begin{tabular}{|l|l|l|}
\hline US20/1:25:32/DM & $\begin{array}{l}\text { Spencer, do you } \\
\text { think I am not } \\
\text { totally terrified all } \\
\text { the time? }\end{array}$ & $\begin{array}{l}\text { Spencer, kau pikir } \\
\text { aku tak ketakutan } \\
\text { sepanjang waktu? }\end{array}$ \\
\hline
\end{tabular}

The above example is a unit shift because there is a shift from phrase to word. In the dialog, it shows that adjective phrase 'totally terrified' in the source language is translated into word 'ketakutan' in the target language.

\subsubsection{Intra System Shift}

Intra system shift is the last type of category shifts. It is a change that occurs internally within a system. Intra system shift happens when a term is singular in the source text and its textual equivalent is plural, or vice versa.

Table 6. Intra System Shift: Plural to Singular

\begin{tabular}{|l|l|l|}
\hline \multicolumn{1}{|c|}{ Code } & Source Language & Target language \\
\hline IS2/1:51:27/CM & $\begin{array}{l}\text { It is hard to find } \\
\text { people. }\end{array}$ & $\begin{array}{l}\text { Sulit mencari } \\
\text { orang. }\end{array}$ \\
\hline
\end{tabular}

In the table above, the word 'people' in the source language is plural and it is translated into 'orang' in the target language which is singular. Although it can be translated into plural form in Indonesia, for example 'orang-orang', so that it will have the same form. The translator decides to have a shift from plural to singular in the translation in order to get more readable result in the target language, therefore it is called as intra system shift.

\section{The Equivalence of Translation}

The researcher analyses the 104 data of adjective phrases that consist of translation shift using Bell (1991) classification of equivalent and non-equivalent meaning. The table below shows the result of the analysis of the translation.

Table 7. Result of The Equivalence of Translation

\begin{tabular}{|c|c|c|c|c|c|}
\hline No & \multicolumn{3}{|c|}{ Equivalence of Meaning } & Number & Percentage \\
\hline 1. & \multirow{3}{*}{ Equivalent } & $\begin{array}{l}\text { Fully } \\
\text { Equivalent }\end{array}$ & $\begin{array}{l}\text { Complete } \\
\text { Meaning }\end{array}$ & 64 & $61.54 \%$ \\
\hline 2. & & \multirow{2}{*}{$\begin{array}{l}\text { Partly } \\
\text { Equivalent }\end{array}$} & $\begin{array}{l}\text { Increased } \\
\text { Meaning }\end{array}$ & 3 & $2.88 \%$ \\
\hline 3. & & & $\begin{array}{l}\text { Decreased } \\
\text { Meaning }\end{array}$ & 26 & $25 \%$ \\
\hline \multicolumn{4}{|c|}{ Total of Equivalent Meaning } & 93 & $89.42 \%$ \\
\hline 1. & \multirow{2}{*}{$\begin{array}{c}\text { Non } \\
\text { Equivalent }\end{array}$} & \multicolumn{2}{|c|}{ Different Meaning } & 11 & $10.58 \%$ \\
\hline 2. & & \multicolumn{2}{|l|}{ No Meaning } & 0 & $0 \%$ \\
\hline \multicolumn{4}{|c|}{ Total of Non Equivalent Meaning } & 11 & $10.58 \%$ \\
\hline \multicolumn{4}{|c|}{ Total } & 104 & $100 \%$ \\
\hline
\end{tabular}

The table shows that the complete meaning has the highest frequency with the occurences of 64 out of 104 or $61.54 \%$. Meanwhile the increased meaning has the 
occurrances of 3 or $2.88 \%$ and decreased meaning has the occurrances of 26 or $25 \%$. Meanwhile, the different meaning has the occurrances of 11 or $10.58 \%$, and for no meaning is zero. Based on the table above, it shows that most of the translation of adjective phrases are equivalent, while the frequency of nonequivalent meaning is very low.

\subsection{Equivalent}

In film subtitles, the translation of English utterances must be equivalent to the original language subtitles. However, some subtitles have a partly equivalent meaning to the original language, but the translation should ideally be totally equivalent to the source language.

\subsubsection{Fully Equivalent (Complete Meaning)}

When the meaning included in the source language text is totally translated into the target language text, this is referred to as fully equivalent or complete meaning. That is, the message conveyed by the source language text is completely conveyed to the intended audience. The following are some examples.

Table 8. Complete Meaning in Structure Shift

\begin{tabular}{|c|l|l|}
\hline \multicolumn{1}{|c|}{ Code } & Source Language & Target language \\
\hline SS33/55:05/CM & $\begin{array}{l}\text { Stealing makes me } \\
\text { very } \\
\text { uncomfortable. }\end{array}$ & $\begin{array}{l}\text { Mencuri } \\
\text { membuatku } \\
\text { sangat tak } \\
\text { nyaman. }\end{array}$ \\
\hline
\end{tabular}

The example above is the example of structure shift due to the change in its structure. The phrase 'very uncomfortable' is translated into 'sangat tak nyaman'. The adjective phrase in the example explains the feeling of the pronoun ' $m e$ '. According to Online Cambridge Dictionary, the word 'very' means (used to add emphasis to an adjective or adverb) to a great degree or extremely. It is translated in Indonesian into 'sangat' which has the same meaning as described in Kamus Besar Bahasa Indonesia Online. Next, according to Online Cambridge Dictionary, the word 'uncomfortable' means not comfortable or relaxed, or feeling anxiety, which has the same meaning as 'tak nyaman' in Indonesian. Therefore, the translation in the target language are fully equivalent and refer to the same meaning.

\subsubsection{Partly Equivalent}

Partly equivalent is divided into increased and decreased meaning.

\subsubsection{Increased Meaning}

Increased meaning happens when there is an addition of information which is not found in the source language text. The examples are shown in the following table.

Table 9. Increased Meaning in Structure Shift

\begin{tabular}{|c|l|l|}
\hline \multicolumn{1}{|c|}{ Code } & Source Language & Target language \\
\hline SS31/51:27/IM & $\begin{array}{l}\text { If my husband } \\
\text { knew I was talking }\end{array}$ & $\begin{array}{l}\text { Jika suamiku tahu } \\
\text { aku bicara } \\
\text { denganmu, kau }\end{array}$ \\
\hline
\end{tabular}




\begin{tabular}{|l|l|l|}
\hline & $\begin{array}{l}\text { to you, you'd be } \\
\text { dead by morning. }\end{array}$ & $\begin{array}{l}\text { bisa mati besok } \\
\text { paginya. }\end{array}$ \\
\hline
\end{tabular}

There is an addition of time complemet in the example above. The translator adds information 'besok' in the target language that can not be found in the source language. According to Kamus Besar Bahasa Indonesia Online, 'besok' means hari sesudah hari ini. That addition can be used to specify the exact time of the complement 'morning' in the source language. This additional of information increases the meaning of the translation.

\subsubsection{Decreased Meaning}

Decreased meaning occurs when a portion of the source language text's meaning is omitted in the target language. The examples are as follows.

Table 10. Decreased Meaning in Structure Shift

\begin{tabular}{|c|l|l|}
\hline \multicolumn{1}{|c|}{ Code } & \multicolumn{1}{|c|}{$\begin{array}{c}\text { Source } \\
\text { Language }\end{array}$} & Target language \\
\hline SS49/1:25:20/DM & $\begin{array}{l}\text { I just got really } \\
\text { insecure or } \\
\text { something. }\end{array}$ & $\begin{array}{l}\text { Aku merasa tak } \\
\text { percaya diri atau } \\
\text { semacamnya. }\end{array}$ \\
\hline
\end{tabular}

In that example, 'really insecure' is translated into 'tak percaya diri'. The translator removes or does not translate the word 'really' to the target language, which can be fully translated into 'sangat tak percaya diri'. According to Online Oxford Dictionary, an adverb 'really' is used to emphasize an adjective or adverb. The word 'really' that is translated into 'sangat' in Indonesian may indicate or mean a greater feeling of insecure that is more than usual. Thus, when the word 'really' is omitted in the target language, the meaning of what is felt by the subject ' $I$ ' will be incomplete. The omission of the intensifier adverb in the target language makes the sense weaker. Therefore, the translation of this adjective phrase has a decreased meaning.

\subsection{Non-Equivalent}

When the source and target languages have a different meaning or no meaning, the translation is non-equivalent..

\subsubsection{Different Meaning}

Different meaning occurs when the translator modifies the information included in the source language text by substituting for terms that have a different meaning in the target language text. Below are the examples.

Table 11. Different Meaning in Class Shift

\begin{tabular}{|l|l|l|}
\hline \multicolumn{1}{|c|}{ Code } & Source Language & Target language \\
\hline CS7/40:11/DifM & $\begin{array}{l}\text { Who wouldn't } \\
\text { want to be better } \\
\text { at geometry? }\end{array}$ & $\begin{array}{l}\text { Siapa yang mau } \\
\text { belajar geometri? }\end{array}$ \\
\hline
\end{tabular}


The term 'better' is translated as 'belajar' in this instance. According to the Online Cambridge Dictionary, 'better' refers to items or persons that are of a higher standard, or are more suited, appealing, or effective than others. While according to Kamus Besar Bahasa Indonesia Online, 'belajar' means berusaha memperoleh kepandaian atau ilmu. Based on those two explanation, it clearly shows that those two words have different meaning which is not connected to one another. Besides, in the movie, the characters talk about the strengths that they have, so it is not about study or learn anything but about the power that they already have in the characters of the game. The word 'better' is better translated into 'lebih baik'. Thus, for the full translation, it would be better translated into 'lebih baik dalam geometri'.

\subsubsection{No Meaning}

No meaning occurs when the translator does not translate a phrase or word in the source language text, hence obliterating all information contained in the source language text in the target language text. This type of equivalent was not discovered throughout this investigation.

\section{CONCLUSION}

Based on the data analysis, there are five types of translation shifts of adjective phrase in the subtitles of Jumanji: The Next Level movie. They are level shift (1.92\%), structure shift (56.74\%), class shift (18.27), unit shift (21.15\%), and intra system shift $(1.92 \%)$. Furthermore, structure shift, as the most often shift that occur, has some pattern of structural changes which are $\mathrm{H}+\mathrm{M}$ into $\mathrm{M}+\mathrm{H}, \mathrm{M}+\mathrm{H}$ into $\mathrm{H}+\mathrm{M}, \mathrm{M}$ $+\mathrm{H}+\mathrm{M}$ into $\mathrm{H}+\mathrm{M}$, and the changes in the position or order of part of speech. It can be concluded that the pattern of changes that occur in the structure shift depends on the arrangement of grammatical structure in both source language and target language. Besides, level shift as the least of shift, only has a pattern of shift from grammar to lexis, while intra system shift has a pattern of shift from plural to singular.

In the case of meaning equivalence, the translation of adjective phrases in the movie Jumanji: The Next Level are mostly transferred equivalently. In addition, the researcher finds total 93 or $89.42 \%$ data of equivalent meaning with 64 data of complete meaning, 3 data of increased meaning, and 26 data of decreased meaning. Meanwhile, there are 11 or $10.58 \%$ data of non equivalent meaning in the category of different meaning. Out of three types of equivalent meaning, complete meaning is the most dominant types of equivalent that occurs in the translation. Therefore, it can be said that the translator is successful in the process of shifting of adjective phrases from source language to the target language because of the high frequency of the equivalent meaning.

Based on on the result of the research, it shows that not all shifts which occur in translation categorized as equivalent. Subtitles, as a translation product which functions to help people to understand the meaning of dialogues, must convey messages correctly from the source language to the target language. However, in the process of translating dialogues into text in the form of subtitles, sometimes there is an omission, addition or alteration in meaning. It happens because the translator tries to adjust to the difference of grammatical structure between source language and target language. Hopefully, this research can give an insight to the world of 
translation studies, especially in terms of translation shift, so that there will be some kind of development in the theory of translation shift.

\section{REFERENCES}

Alwi, Hasa. (2003). Tata Bahasa Baku Bahasa Indonesia. Jakarta: Balai Pustaka

Bassnett, Susan. (2002). Translation Studies, 3rd edition. London: Routledge

Bell, R. T. (1991). Translation and Translating: Theory and Practice. London: Longman

Brislin, Ricard. W. (1976). Translation: Application and Research. New York: Gardner Press Inc.

Cambridge Dictionary. (2021). Cambridge Dictionary. https://dictionary.cambridge.org/dictionary/

Catford, J. C. (1965). A Linguistic Theory of Translation: An Essay in Applied Linguistics. Oxford: Oxford Univ Press

Choliludin. (2007). The Technique of Making Idiomatic Translation. Jakarta: Kesaintblanc

Dixson, R.M.W. (1982). Where Have All The Adjective Gone? and other Essays in Semantics and Syntax. Berlin: Motion

Frank, Marcella. (1972). Modern English: Part 1. Englewood Cliffs, N.J.: Prentice-Hall

Greenbaum, Sidney. (1996). The Oxford English Grammar. New York: Oxford University Press

KBBI Daring. (2016). KBBI Daring. https://kbbi.kemdikbud.go.id

Machali, R. (1998). Redefining Textual Equivalence in Translation with Special Reference to Indonesian-English. Jakarta: Pusat Penerjemahan Universitas Indonesia

Nafisah, N., Hartono, R., and Yuliasri, I. (2019). "Translation Methods And Degree Of Equivalence In English-Indonesian Translation Of Leo Tolstoy's “God Sees The Truth But Waits"'”. Rainbow : Journal of Literature, Linguistics and Culture Studies, Vol. 7, No. 2, pp. 1-10

Nida, E. A., and Taber, C.R. (1969). The Theory and Practice of Translation. Leiden: E.J. Brill

Nida, E. A. (1975). Language Structure and Translation. California: Stanford University Press 
59 J-Lalite: Journal of English Studies Vol.2, No.2, December, 2021

Oxford Learner's Dictionary. (2021). Oxford Learner's Dictionary. https://www.oxfordlearnersdictionaries.com/

Permadi, Taufik Budi. (2013). A Translation Shift Analysis of Verb Phrase in Subtitling of The Expendables 2 Movie. Surakarta, ID: Muhammadiyah University of Surakarta

Ratnawati, Ririn. (2013). A Translation Shift of Noun Phrase in The Dark Knight Rises Movie and Its Subtitling. Surakarta, ID: Muhammadiyah University of Surakarta

Savory, Theodore. (1968). The Art of Translation. London: Cape

Shuttleworth, Mark., and Cowie, Moira. (1997). Dictionary of Translation Studies. Manchester, UK: St Jerome Publishing

Tailor, G. R. (Ed.). (2005). Integrating Quantitative and Qualitative Methods in Research. Maryland: University Press of America Inc.

Todd, Loreto. (1987). An Introduction to Linguistics. London: Longman York Press 